\title{
The IT Aspect: Towards a More Efficient System-Control and Audit of EU Funds for the Cohesion Policy
}

\section{Judit Fortvingler}

Faculty of Economic and Social Sciences

Budapest University of Technology and Economics

Magyar tudósok körútja 2, H-1117 Budapest, Hungary

E-mail: fortvingler@finance.bme.hu

Abstract: Assuming that not more audits but better coordinated ones are preferred, the key objective of the article is to explore how deeper exploitation of the current IT background could improve the efficiency of audits and controls of EU funds for Cohesion policy. After presenting the internal control and external audit functions, various scenarios of IT utilization which form different levels of IT convergence are delineated. Finally, the author concludes that audit and control activities could be further developed, particularly by a more extensive use of the IT background. From a professional point of view, direct access to core national databases would provide auditors with additional information on systems at Member States level. The research method applied was interviews with professionals of the European Court of Auditors, as well as with the developer of the Unified Monitoring Information System and different authorities in Hungary. In addition, documents were consulted which are available at the Historical Archives of the European Union and the European Court of Auditors, through the Postgraduate Research Grant Programme, which offered a unique opportunity.

Keywords: Unified Monitoring Information System; multi-level assurance system; Cohesion policy

\section{Introduction}

The EU funds assigned to the Cohesion policy in support of growth and jobs represent over one-third of the total budget. The allocation of these funds to final beneficiaries is carried out under a complex system, where the implementation and the control activity are shared between the European Commission and 
Member States ('shared management') ${ }^{1}$. The Member States bear primary responsibility for creating an effective management and control system, while the European Commission plays a supervisory role. Witnessing a growth in audit costs for the programming period 2007-2013, the European Court of Auditors (hereinafter the Court) assessed the estimated error rate to exceed five percent and identified serious deficiencies in shared management areas (ECA, 2012a). One may say that an error rate of about five percent is a good and acceptable value. However, an estimated error rate surpassing two percent, which is generally used by the European Court of Auditors as the 'materiality threshold', implies a qualified opinion on the implementation of the EU budget, that stakeholders expect not to have.

To curb the increasing costs and push the high error rate down, they suggested improvements in cooperation and coordination between the different actors of the existing control and audit systems (European Commission DG Regional Policy, 2010; European Parliament, 2011).

Even though existing literature that focuses on cooperation is already extensive, it mainly examines two aspects. On the one hand, the cooperation between the Court and supreme audit institutions (SAI's) has been dealt with for years (Castells, 2005). The pilot project on coordinated audit and the activity of the Contact Committee of the Supreme Audit Institutions present remarkable examples of their commitment to achieve a higher degree of collaboration. On the other hand, the Commission's internal control framework has been reviewed by scholars numerous times. It is a common view that the Commission has made tremendous efforts to construct its multi-level assurance system in order to accomplish smoother financial management. Nevertheless, some information stored in the computerised system has not yet been fully exploited.

The objective of this article is to address this deficiency by investigating how the IT aspect can add value to the work of auditors and controllers. This leads to the key research question: How can the existing IT background enhance the efficiency of audits and controls for Cohesion policy?

The article is structured as follows. First, the author describes the audit and control system of shared management and gives insight into the efforts made in the past to create a system where reliance on others' work is a key factor. Secondly, the most significant challenges of the current system are revealed. Finally, the potential role of IT in expediting the process of convergence, which in turn defends the EU's financial interest, is examined. The conclusion summarizes the research findings and their implications.

1 Although the agricultural expenditure formulates the other pillar of EU funds under shared management, this article concentrates on the poliy area of Cohesion. 
The empirical background for the answer to the research question includes regulatory frameworks, both at EU and national level, and interviews with professionals of the European Court of Auditors, the State Audit Office of Hungary, the Directorate General for Audit of European Funds (audit authority), the National Development Agency (managing authority), and the developer of the Unified Monitoring Information System. In addition, academic publications and internal documents of the Court, the latter available through the Postgraduate Research Grant Programme, served as a solid basis for the research.

\section{The Multi-Level Assurance System for Cohesion Policy}

\subsection{The Audit and Internal Control Functions}

The Commission holds the overall responsibility for the implementation of the EU budget in accordance with the relevant regulations. For funds of the Cohesion policy under shared management, the management and control activities are performed in cooperation with Member States. Hence, each Member State has to put in place an adequate management and a multi-level control system, both of which guarantee sound financial management of EU funds while ensuring regularity and eligibility of the expenditures made from these funds. At the top of the internal control system, the Commission itself, in addition to the audit activity of the Directorates-General, has its own Internal Audit Service.

Why is system quality such a key factor for auditors? As an external guardian, the European Court of Auditors is in charge of scrutinizing public spending and safeguarding the financial interests of EU citizens. The Court adopts the so-called system-based approach, which means that audit engagement starts with a thorough analysis of the auditee's internal control system, to collect evidence that proves it is functioning effectively. If system assessment shows that it is operating well, the extent of direct testing can be reduced. This is fundamental to understanding why the quality of any system has crucial importance for auditors.

Currently, neither the Court's nor the Commission's auditors have direct access to national IT databases; they receive core data on request from SAI's or other authorities.

Table 1

The internal control and external audit systems

\begin{tabular}{ccc}
\hline $\begin{array}{c}\text { at national level (Member } \\
\text { States) }\end{array}$ & Implementing authorities & Supreme Audit Institutions \\
\hline at European Union level & $\begin{array}{c}\text { Directorates-General } \\
\text { Internal Audit Service }\end{array}$ & European Court of Auditors \\
\hline
\end{tabular}


Prior to analysing how the existing IT background could enhance control and audit activities, one must know the elements of the complex control system at the national level. As implied in the provisions of the current regulatory framework, each Member State has to assign certain authorities with different mandates: a managing authority, a certifying authority, an audit authority, and optionally, intermediate bodies.

The managing authority's main task is to implement the EU budget at the national level, complying with the principle of sound financial management. To fulfill its duty, it certifies that the expenditure declared by beneficiaries satisfies the conditions of the approval decision and the EU and national rules. In addition, the authority submits reports on the implementation to the Commission and evaluates operational programmes. With respect to IT, the managing authority ensures that an adequate computerised system records and stores core data for planning, verification, audit, and evaluation purposes, which provides the certifying authority with all the necessary information to verify the expenditure to the Commission. The managing authority's control activity consists of, on the one hand, administrative verifications for invoices submitted by beneficiaries, and on the other hand, on-the-spot verifications of projects. To expedite the flow of information, documents of verifications have to be available for other actors of the control and audit systems. In Hungary, the National Development Agency, under the surveillance of the Government Commissioner for Development, has been designated as the managing authority.

The intermediate bodies are optional elements of the control system. They perform on-the-spot checks, the frequency of which varies depending on the volume of the funds the beneficiary is entitled to receive. The managing authority supervises the activities of intermediate bodies by investigating the selection procedures of, in general, at least 5 percent of the projects. In Hungary, there are several intermediate bodies that the managing authority can delegate some of its tasks to $^{2}$.

Within the whole project cycle, the managing authority and the intermediate bodies are primary users of the IT system, which provides them with core data for different purposes (e.g. monitoring, risk-based sampling). Unlike auditors, their principal duties do not include data analysis for system assessment.

The certifying authority is responsible for submitting certified statements of expenditure and applications for payment to the Commission. Its control activity includes both on-the-spot and administrative checks at the organizations taking part in the implementation. The authority ensures that the statement of expenditure and the underlying transactions are accurate and admissible, stemming from reliable accounting systems. Taking the example of Hungary, the State Treasury,

2 The tasks and a list of designated intermediate bodies are laid down in a government decree. 
under the governance of the Minister of National Economy, is assigned to act as a certifying authority.

Finally, the heart of the audit authority's activity is to verify that the management and the control system are functioning effectively. To fulfill its duty, the authority performs system audits and project audits of a randomly drawn statistical sample. The sample to be audited each year has to be drawn from the expenditures submitted to the Commission in the preceding year. During on-the-spot audits, the original documentation held by beneficiaries is examined for comparison with the expenditures declared and subsequently recorded in the IT system. Moreover, compliance with the selection criteria and approval decision in the implementation phase is evaluated.

The authority annually issues an opinion about whether the management and control system is functioning effectively, in order to provide a reasonable assurance that statements of expenditure submitted to the Commission are accurate and that the underlying transactions are legal and regular. The audit authority must have all the information needed to form an opinion. That is why its activity is perceivable at each level of the control chain. Finally, as the main cog in the machinery of the control chain, the Commission supervises the operation of the audit authority. It may conclude that it can rely on the opinion issued by the audit authority; thus, the Commission will perform on-the-spot audits only if there is evidence of deficiencies in the national system.

In Hungary, the Directorate General for Audit of European Funds, under the governance of the Minister of National Economy, has been given the role of audit authority.

The elements of the multi-level assurance system for EU funds under shared management are presented below.

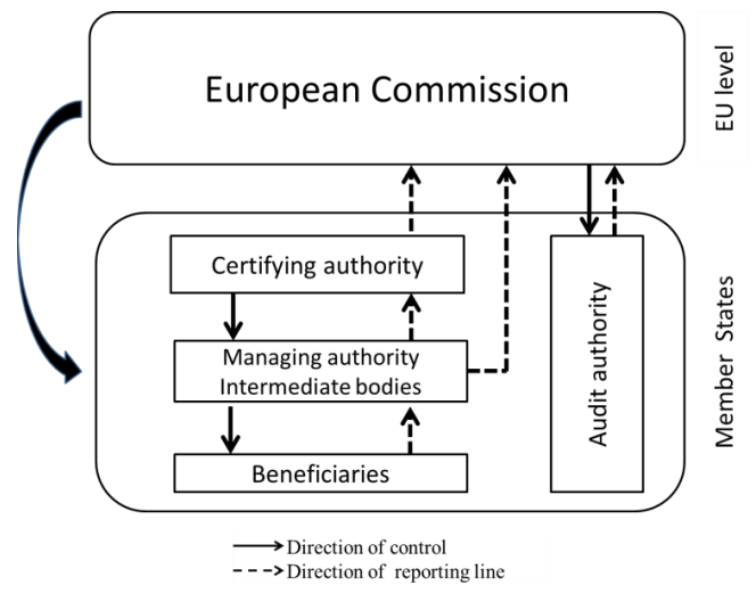

Figure 1

The multi-level assurance system 
Both the certifying authority and the audit authority have direct access to the national IT database. During the interviews, a modest communication gap was observed between what the developer of the Unified Monitoring Information System (UMIS), the IT background operating in Hungary, has been told the UMIS should be capable of and what its users can actually expect from it. Consequently, there must be room for a better use of IT resources by enhanced communication.

\subsection{The Challenges of the Current Control and Audit Systems}

The Cohesion policy has been spotlighted over the past few years due to deficiencies in the control system and the high error rate, which is still over five percent. Not surprisingly, this area is a risky business by nature. The most hazardous characteristics of the systems are (Weber, 2010):

- the large number of beneficiaries;

- the numerous authorities at national level;

- the pressure to absorb the EU funds;

- the complex regulatory framework.

Mendez et al. (2011) argue that the Commission's administrative reform has generated an audit and control explosion in the field of Cohesion policy since the mid-2000s. Besides the internal organizational change, the drive to achieve a positive Statement of Assurance ${ }^{3}$ and the intention to improve the internal control framework all contributed, as a secondary effect, to the intensification of audit and control activity. A study on the implications of the legislation for cost effectiveness of structural funds affirmed that the programming period of 20072013 has experienced a massive increase in the audit effort (European Parliament, 2011). Some scholars share the idea that the quantity of audits is sufficient; therefore, not more audits but better coordinated ones are desirable. To resolve the problem of increasing audit costs, a stronger cooperation and coordination between auditors at different levels has been suggested. With respect to internal control, the so-called 'single audit model' (Cipriani, 2010) has become widely accepted, a model which favours the idea that different building blocks of the system place assurance on the work of previous controls performed by lower layers, which diminishes the danger of duplication. Regarding external audit functions, there is increased cooperation between the Court and SAI's. Though the Treaty of Amsterdam declares that the Court and the SAI's 'shall cooperate in a spirit of trust while maintaining their independence, these institutions witness implementation problems caused by different mandates and dissimilar relationships with their national parliaments. A pilot project on coordinated audit, with the participation of the Court and a few SAIs, proved that this divergence

3 The Court's opinion on the reliability of the EU accounts, and on the legality and regularity of the underlying transactions 
represents a real challenge for the auditors and has an impact on future cooperation.

To conclude, one can hardly expect that with enhanced cooperation between audit and control functions these bodies can tackle the problematic issues of increasing costs and material error rate in the short term. What other possibilities are there to exploit the full potential of the current system? IT is certainly one.

\section{The IT Aspect}

The general principles of the management and control systems, established according to the provisions of Commission Regulation (EC) No. 1083/2006, include the stipulation that Member States shall arrange for 'reliable accounting, monitoring and financial reporting systems in computerised form'. In addition, the Regulation delegates to the managing authority the duty of operating such a system, which records and stores all the data on implementation necessary for the financial management of funds, monitoring, verification, and audit activities. Furthermore, the certifying authority should have accounting records of expenditure confirmed to the European Commission in computerised form.

It is of prime importance to emphasise that regulatory framework at EU level defines neither the detailed characteristics nor the correct structure of such an IT system, but rather it stipulates features it must be capable of (e.g. recording and reporting financial transactions, irregularities, and financial corrections imposed by Member States).

Turning to the national context, the UMIS has been developed to store and synchronize all the core data for policy areas financed by the European Regional Development Fund, the European Social Fund, and the Cohesion Fund. The complexity of UMIS forms a basis for monitoring and ex-post audit activities, as it covers the whole project cycle: from planning until evaluation:

- electronic submission of applications, automatic input of electronic applications;

- on-line information for applicants (status of application/ project, contract modifications, submission of missing underlying documents);

- electronic submission of payment claims (input of invoices);

- electronic submission of project reports (input of indicators into UMIS monitoring module);

- data input from web based functions is stored in a separate web database and automatic data exchange occurs every 10 minutes, which synchronizes core data among systems;

- public information on the managing authority's website (statistics, reports, report generators). 
Data exchange occurs with public databases. For instance, the UMIS provides the national monitoring system of the Hungarian State Treasury with project and payment data, and the account management system of the Treasury with electronic payment requests. Additionally, the National Tax and Customs Administration of Hungary makes certain information available to the UMIS, as beneficiaries of EU funds are not allowed to accumulate tax or other public charge obligations. Otherwise, the reimbursement is suspended.

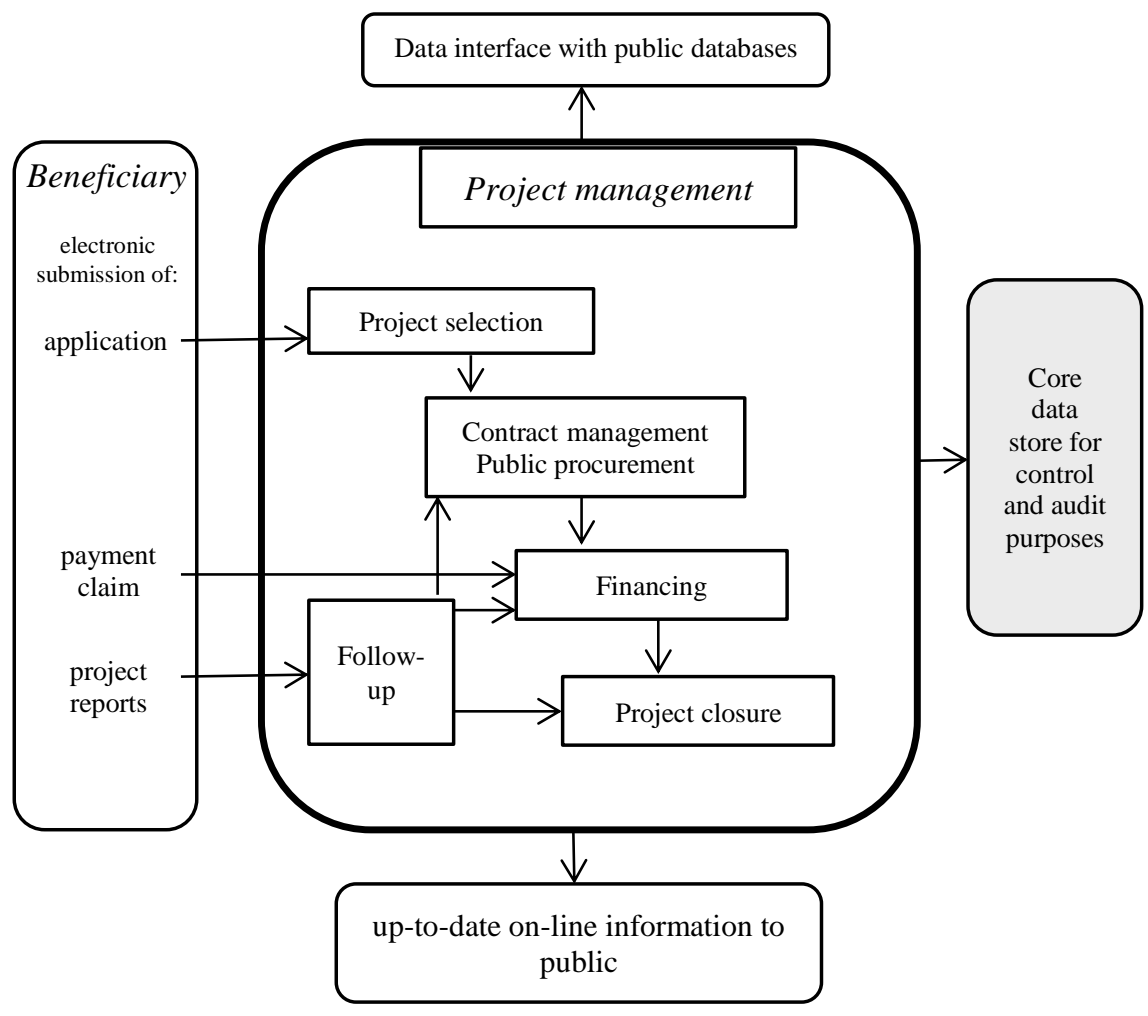

Figure 2

The complexity of UMIS

The increasing cost of controls and audits has been a cause of concern for a number of years. This article puts forward the idea of how the existing non-human resources (e.g. IT) could be better exploited without requiring additional financial resources. How could the IT systems add value to audit and control functions to make audits more efficient? How could the UMIS contribute to transparency in the utilization of EU funds and support the work of both external and internal auditors at the EU and national levels?

In fact, the degree of contribution greatly depends on the level of IT system convergence and rights of access, and thus several scenarios exist. Level 1 represents the current situation, where each Member State has its own IT system, 
and auditors at EU level have no direct access to national IT systems. Consequently, data service, required by the Court or the Commission for audit purposes, is time-consuming, as, in the long information chain, it sometimes goes back too slowly to the developer of the UMIS. The interviews with professionals of the Court revealed a perceptible time lag in data transfer, which has an influence on the timing of audit visits to Member States. On the other hand, data transferred to EU auditors appears to be rather stocktaking in manner; it includes funds which have been allocated to certain projects / programmes at a given time. Owing to the lack of access to core data, no further conclusions could be drawn from analysing changes in historical data recorded in the IT system, with respect to the overall functioning of the management and control systems.

Level 2 suggests a more developed and coordinated system, built on a stronger exploitation of the UMIS. In this scenario, the national IT systems remain unchanged but EU auditors have direct access to those systems. From the IT aspect, it could easily be solved and it is a cost-effective way of utilizing the existing sources.

In parallel, what kind of benefits could be achieved for auditors of funds of Cohesion policy? First, direct access by the Court and the Commission to core data stored in the UMIS would result in time savings due to the elimination of time-consuming data inquiries from the supreme audit institutions and audit authorities at the national level. This is rather a technical point of view. More importantly, from the professional aspect, direct audit evidence could be gained for system assessments with respect to management and control systems operating in Member States. Unlike Level 1, either the database could be analysed or the control activity of the managing authorities or intermediate bodies could be examined. Hence, it would be possible to bring together additional information for system assessment, which greatly influences the extent of substantive testing.

The direct access to core database addresses the issue of transparency. Cipriani (2010) emphasises that financial correction often manifested in substitution of ineligible cost, and 'Member States tend to over-declare national expenditure in order to create a buffer of eligible items'. Although the regulatory framework permits such substitutions, there is considerable debate as towhether this practice is desirable and conforms to the original aim of Cohesion policy. In this field, the Court suggests some issues for consideration. First, ineligible expenditure might be systemic by nature, and if not addressed appropriately, it can be substituted by another ineligible one. Secondly, if the replacing expenditure has originally been financed by national funds, 'cohesion spending is turned into ex post support for the budgets of Member States' (ECA, 2012b). The Commission's view on substitution of ineligible expenditure is that Member States should have the right to make such changes to optimize the utilization of EU funds if deficiencies appear at national level. In case of direct access to core database, auditors would have insights into the practice of substitution of ineligible expenditure by new expenditure, which would be an additional source of information when 
determining the outcomes of system assessment. At first sight, one can expect that difficulties may derive from the fact that auditors have to be familiarised with national IT systems. However, this obstacle can definitely be overcome; auditors frequently face the challenge of getting to know different IT systems and solutions in their day-to-day activities (e.g. computer-assisted audit techniques - CAATs).

To sum up, a slight change (direct access to core data) at the IT level, though supported by professional arguments, opens up a more political point of view.

Finally, level 3 represents the pinnacle of IT convergence. At this stage, Member States use a unified IT system for recording and storing data of EU funds. The advantages of the previous level could be enumerated here as well. In addition, time savings could be reached deriving from not having to know the diversity of IT systems across the EU. From the aspect of auditing, this alternative is the most 'convenient' way of collecting data for system assessment and for sampling. To a large extent, the unified IT system at EU level is inevitably a politically sensitive question; it would require political consensus at the highest level, embedded in EU legislation, and not modus vivendi.

Table 2

Scenarios of management and monitoring IT systems convergence

\begin{tabular}{|c|c|c|c|}
\hline $\begin{array}{l}\text { Characteristic of } \\
\text { IT system }\end{array}$ & $\begin{array}{c}\text { Degree of } \\
\text { convergence }\end{array}$ & Pros & Cons \\
\hline \multirow{2}{*}{$\begin{array}{l}\text { National IT system } \\
\text { for recording and } \\
\text { storing core data }\end{array}$} & $\begin{array}{l}\text { Level 1 } \\
\text { No access to } \\
\text { national IT systems } \\
\text { by EU auditors }\end{array}$ & $\begin{array}{l}\text { - Right of access } \\
\text { does not occur }\end{array}$ & $\begin{array}{l}\text { - Time-lag in data } \\
\text { transfer (difficulties } \\
\text { in planning of audit } \\
\text { visits) } \\
\text { - Lack of deep } \\
\text { analysis of core data } \\
\text { (narrowing } \\
\text { information for } \\
\text { conclusion) }\end{array}$ \\
\hline & $\begin{array}{l}\text { Level 2 } \\
\text { Direct access to } \\
\text { national IT systems } \\
\text { by EU auditors }\end{array}$ & $\begin{array}{l}\text { - Time savings, } \\
\text { cost-effectiveness } \\
\text { - Additional audit } \\
\text { evidence for system } \\
\text { assessment } \\
\text { - Core data base } \\
\text { analysis } \\
\text { - Higher level of } \\
\text { transparency }\end{array}$ & $\begin{array}{l}\text { - Tackling right of } \\
\text { access } \\
\text { - Variety of IT } \\
\text { system put in place } \\
\text { by Member States }\end{array}$ \\
\hline $\begin{array}{c}\text { Unified IT system } \\
\text { at EU level }\end{array}$ & $\begin{array}{c}\text { Level } 3 \\
\text { Direct access to } \\
\text { unified IT system by } \\
\text { EU auditors }\end{array}$ & $\begin{array}{l}\text { - Time savings } \\
\text { - Easier data } \\
\text { collection for } \\
\text { system assessment } \\
\text { and sampling }\end{array}$ & $\begin{array}{l}\text { - Political sensitivity } \\
\text { - Additional } \\
\text { regulation for the } \\
\text { unified system }\end{array}$ \\
\hline
\end{tabular}


Irrespective of the level of convergence and hence the extended access rights of data, even in the current circumstances, stronger cooperation and communication are advised so that the IT background could satisfy auditors' needs. This goes far beyond the written provisions of the regulatory framework, and it requires a contiguous interaction between different fields, e.g. IT, auditing, and project management.

\section{Conclusions}

The Cohesion policy, while complex in its implementation, is definitely one of the most exciting and in the meantime one of the most risky businesses of the European Union. While audit and internal control efforts have experienced a tremendous increase, the error rate (the proportion of ineligible items) is still over 5 percent. However, stakeholders expect the control and audit explosion to bear fruit and result in smoother financial management over all the European Union.

Scholars primarily investigate the development of the internal control system of EU funds and the enhancing cooperation between the Court and the SAI's when searching for the remedy for the high error rate. Less attention has been paid to the potential of the existing IT resources to support controllers and auditors. It was detectable during interviews prepared at the Hungarian and even the EU level that the IT aspect, as a source of evidence for audit purposes, has not yet been fully exploited.

This author finds that a higher convergence between IT systems at the EU level would result in a more efficient audit system. As a first step, the right of access to core data stored in national databases opens up the possibility for auditors to draw conclusions on system assessment by the analysis of historical data. The increasing transparency over EU funds due to access to core data would shift Member States to a more efficient implementation of the budget, which could result in a diminishing error rate. This is not to say that an even stronger cooperation between SAIs and the development of the internal control system is not worthwhile. It should be emphasised that the IT aspect is only one of the building blocks of a complex system that could help secure EU citizens' interests in achieving the original goal of the Cohesion policy.

After having examined how the current IT background could contribute to a more developed and effective audit system of EU funds in general, for further research, it is beyond dispute worthwhile exploring how the functionality and interfaces of such an integrated IT system could be built up in such a way as to reflect the expectations of different players of the whole EU budget system.

\section{Acknowledgement}

The article is based on the author's presentation made at the European Court of Auditors in Luxembourg on October 26, 2011. This work was supported by the Postgraduate Research Grant Programme created by the European University Institute (Historical Archives of the European Union) and the European Court of Auditors. 


\section{References}

[1] Castells, A.: "External Audit Institutions: the European Court of Auditors and its Relationship with National Audit Institutions of the Member States", in: Public Expenditure Control in Europe, 2005, pp. 127-147

[2] Cipriani, G.: “The EU Budget: Responsibility without Accountability?”, Brussels, Centre for European Policy Studies, 2010

[3] Cipriani, G.: "The Responsibility for Implementing the Community budget", Brussels, Centre for European Policy Studies Working Document, No. 247/June 2006

[4] European Commission: "Synthesis of the Commission's Management Achievements in 2010", Communication to the European Parliament, the Council and the Court of Auditors, Brussels, 1.6.2011

[5] European Commission DG Regional Policy: "2010 Annual Activity Report”, Brussels, 31st March 2011, http://ec.europa.eu

[6] European Court of Auditors: "Annual Report on the Implementation of the Budget”, 2012a, http://eca.europa.eu

[7] European Court of Auditors: "Structural funds: Did the Commission Successfully Deal with Deficiencies Identified in the Member States' Management and Control Systems?", Special report, No. 3, 2012b, http://eca.europa.eu

[8] European Parliament, Directorate-General for Internal Policies: "What are the Implications of the Current Legislation for Cost Effectiveness and Quality Control in Structural Fund Spending? What Role for Performance Auditing?", Brussels, 2011

[9] Levy, R.: "Managing Value-for-Money Audit in the European Union: the Challenge of Diversity", Journal of Common Market Studies, 1996, Vol. 34, pp. 509-529

[10] Mendez, C. and Bachtler, J.: "Administrative Reform and Unintended Consequences: an Assessment of the EU Cohesion Policy "Audit Explosion”, Journal of European Public Policy, August 2011, pp. 746-765

[11] Mendez, C. and Bachtler, J.: "Who Governs EU Cohesion Policy? Deconstructing the Reforms of the Structural Funds", Journal of Common Market Studies, 2007, Volume 45, Number 3, pp. 535-564

[12] Treaty on the Functioning of the European Union, available on http://eurlex.europa.eu

[13] Weber, M.: "European Court of Auditors' Approach to the Audit of Cohesion Policy", Seminar on ECA DAS Methodology and Audit Missions in Member States, Budapest, 18 November 2010 